\title{
Adjustment in General Equilibrium: Some Industrial Evidence
}

\author{
Farhad Rassekh* \\ Henry Thompson
}

\begin{abstract}
The link between output changes and factor-mix adjustments in general equilibrium is examined tor each of nine industries using pooled data trom 12 developed countries over the years 1970-85. Specifications of the Stolper-Samuelson theorem and the specific-faciors model of production are built on the assumptions and structure of theory with each industry isolated in tum. In their simplest version with only capital and lator ispur, these competitive general-equilibriwn models explain a good deal of the observed variations in iudustrial factor mixus. The specific-factors model performs betrer.
\end{abstract}

\section{Introduction}

The theory of production and trade is built in large part on the competitive paradigm contained in general-equilibrium models of production. The Stolper-Samuelson theoIem (1941) of the Heckscher-Oblin model captures the link between an industry's price and the retum to its intensively used factor of production, illustrated in Edgeworth box and Lerner-Pearce diagrams. The specific-factors model assumes every industry is characterized by productive capital used only in that industry, creating a direct link between the price of an output and its specific factor.

This paper provides some empirical evidence for the Stolper-Samuelson theorem and specific-factors model. Model specifications are estimated using data for each of nine manufacturing industries across 12 OECD countries from 1970-85. In the StolperSamuelson specification, a rising price in an industry causes the capital-labor ratios to adjust according to factor intensity. In the specific-factors model, a bigher price in an industry is expected to increase labor input.

There are data available for many industries, suggesting a model with many goods. When the prices of goods are exogenously given at world levels, however, a production model with two factors shared by each industry is overdetermined. Introducing demand allows a tractable model, but relaxes the intensity links. The present paper isolates each industry and aggregates the others into a single sector, developing a series of two-sector models to coincide with the Stolper-Samuelson theorem.

Leamer (1994a) argues that an idea needs an issue, a theory, and evidence to survive. The Stolper-Samuelson theorem meets the first two conditions, but lacks much of the third. The theorem was originally presented and applied largely in the context of

\footnotetext{
* Rassekb: University of Hartford, CT 06117, USA, Tel 860-768-5007, Fax: 4198, E-mail: rassekh@uhayax.hartford.edu. I'bompson; Aubura University, AL. 36849, USA. Tel; 334-844-2910, Fax 4615. E-mail: brhompsn@businestalabum.edu. Al Radkee III and Michael Spellacy provided excellent research ussistance. Jay Steward kindly provided helpful consultation on S.AS for the empirical estimation. Thanks for suggestions offered by Kei-Mu Yi, Par Conway, and Zhunhui $\mathrm{X}_{\mathrm{u}}$ at the 1994 Southeast Economic Theory and Lntemational Trade Conference at the University of Virginia. Mlanouchehr Mokhtari was a helpful consultant Two referees of this journal made detailed suggestions which improved the paper. The usual disclaimer applies.
} 
intemational trade theory. The general-equilibrium model can, however, describe a totally closed economy experiencing demand-driven price changes. If the demand for a good rises, its price increases and the Stolper-Samuelson theorem predicts relative factor-price adjustment. This link between prices of goods and prices of factors through the production structure, holding technology constant, is the heart of the Stolper-Samuelson theorem. When the price of a good changes, outputs adjust as productive factors shift between industries. The present paper adopts this general perspective without a direct link to trade or trade policy.

The appeal of the Stolper-Samuelson theorem stems from its clear identification of winners and losers. Economists concerned with income redistribution due to trade policy often invoke the theorem. Tariffs are generally thought to favor relatively scarce factors of production and harm relatively abundant factors. Whether and how this intuition applies to an economy composed of many industries remains an intriguing puzzle. This paper provides one approach to interpreting and applying the theorem.

\section{The Isolated-Industry Model and the Specific-Factors Model}

With many factors and goods, there are unambiguous factor-intensity rankings only under very restrictive conditions, as developed by Chang (1979) and Ethier (1984). Output in industry $j$ is a function of capital and labor inputs, $x_{j}=x_{j}\left(K_{j}, L_{j}\right)$. Assume homothetic neoclassical production liunctions. With competitive pricing, cost equals price. Unit-value isoquants represent the amount of good $j$ worth one unit of numeraire, namely one US dollar. The isolated-industry model simplifies the economy to only two sectors, leading to unambiguous predictions depending on industrial factor intensity. Other manufacturing output is aggregated into $x_{v}$.

The isolated industry $j$ is labor intensive if $(K / L)_{j}<(K / L)_{0}$. Let the price $p_{l}$ of this labor-intensive good rise, holding constant the price of the other good and total endowments of capital and labor available in manufacturing. The expanding industry hires more labor per unit of capital than in the contracting sector, relative wages rise, and both industries become more capital intensive. Output of the labor-intensive good increases while output in the other sector drops. Symmetrically, higher price for a capital-intensive good would result in lower relative wages and capital-labor ratios. This dependence on factor intensity captures the essence of the Stolper-Samuelson theorem.

Suppose capital is a specific factor, as in Jones (1971), Samuelson (1971), and Neary (1978). Some of the capital equipment used in these industries cannot easily be converted for use in other industries. Except for some technical workers, the majority of labor in most groups (janitors and economists, for instance) can work in diflerent industries. There are nine industries in the present specific-factors model, each with its own specific capital input. Labor is the common factor, being mobile between industries. Labor and each industry's capital are fully employed and a unique labor input is determined in every industry. A higher price in industry $j$ would shift the unit-value isoquant toward the origin. The supporting isocost line in industry $j$ becomes steeper, as the return to capital rises proportionately more than the wage. Labor enters the sector and output increases, with specitic capital fixed.

\section{Previous Empirical Studies}

Empirical studies of the Stolper-Samuelson theorem are relatively rare, perhaps because the real world does not appear to conform to assumptions of the theory. It is 
known that there are more than two separable inputs in these production processes. Branson and Monoyios (1977) argue that skilled labor is an important input in observed trade. Clark, Hofler, and Thompson (1988) show that there are at least nine separable skill rypes of labor in a cross-section study of US manufacturing. Leamer (1984) successfully specifies a model with different types of labor, capital, and resource inputs.

Magee (1980) makes the first attempt at empirical investigation of the StolperSamuelson theorem, pointing out that the theorem predicts labor and capital would lobby on opposite sides of trade policies. Testimony of groups representing labor and capital before the US Congress on the Trade Reform Act of 1973 shows that lobbying activity occurred along industry lines rather than factor lines. Magee points out, however, that lobbying is more concerned with the short run, while the Stolper-Samuelson theorem is a long-run proposition. Magee's interpretation is in accord with the point of Leamer (1994a) that trade theories should not be "tested" in order to be accepted or rejected. Leamer argues that tests should simply suggest conditions under which a theory is applicable and capable of making predictions.

Leamer (1984) points out that direct econometric estimation of Stolper-Samuelson effects is difficult because of the high degree of collinearity between prices of goods and prices of factors. Detailed and reliable data on factor prices, especially capital, are not available. Moreover, a change in technology or other exogenous supply shocks would alter the relation between prices of goods and factor prices. Leamer appeals to Samuelson's reciprocity relation between the Stolper-Samueison and Rybczysski theorems in order to estimate Stolper-Samuelson effects, focusing on the effects of tariffs on factor prices. The model is not judged by the estimates but is used as the iramework for estimation. Leamer (1994b) applies the same procedure to estimate the wage effects of free trade between the US and Mexico.

Gaston and Trefler (1994) directly estimate the effect of tariffs on US manufacturing wages, which they find to be negative. They believe less efficient resource allocation under protection may be the cause. Workers may also receive economic rent from tariffs by avoiding the cost of searching for new jobs.

Krugman and Lawrence (1994) examine the factor-price equalization theorem based on the logic of the Stolper-Samueison adjustment process. If factor prices across countries are to become equal through trade, they would generally have to move in the direction predicted by the Stolper-Samuelson theorem. Increased international trade is expected to raise the price of a country's abundant factors and reduce the price of its scarce factors. Such a change would lead all industries to substitute scarce factors for abundant factors as trade increases. In the US, relatively scarce unskilled workers should be substituted for abundant skilled workers. Krugman and Lawrence find that this prediction does not hold between 1979 and 1989, a period when international trade increased. Thompson (1985) points out, however, that models of production with as few as three factors do not have such straightionward predictions.

Lawrence and Slaughter (1993) set out to determine whether international trade has caused the slow growth in real hourly compensation and the increase in income disparity in the US since 1973, using the Stolper-Samuelson theorem as a conceptual framework. Their empirical analysis suggests that increased trade and the StolperSamuelson process had little influence on relative wages in the US during the 1980s.

Bhagwati and Dehejia (1993) critically evaluate several recent empirical works, mostly by labor economists, which rely on the Stolper-Samuelson mechanistn to determine the impact of international trade on US wages. They find major theoretical 
pitfalls in these works, and contend that the Stolper-Samuelson theorem is not an adequate guide to reality.

In summary, there is little consensus in the empirical literature. The present paper's contribution lies in specifying empirical models built directly on the theory, controlling for exogenous variables.

\section{Industrial Factor-Intensity Rankings}

The International Sectoral Databank (OECD, 1989) provides data for nine manufacturing industries in 12 developed countries. Two advantages of this data set are consistency across countries and the inclusion of capital input. The data cover the years $1970-85$, and are expressed in 1980 US dollars.

The first step in implementing the Stolper-Samuelson theorem is to rank industries in each country by factor intensity. The average ratio of capital to labor over the entire time period is calculated. Table 1 presents the rankings by capital-labor ratios. For each industry, the first number shows its ranking, with 1 as the most labor intensive. The number following in parentheses is the capital-labor ratio in thousands of dollars of capital per worker. Industries are compared with the capital-labor ratio in total manufacturing, which appears in parentheses along the last row. Each industry is calssified as either $L$ (labor intensive) or $K$ (capital intensive) relative to aggregate manufacturing in each country.

There is a fairly consistent factor-intensity ranking of industries. In every country, textiles (TX), other manufactures (OM), wood (WD), and machinery and equipment (ME) are labor-intensive industries. Chemicals (CH) and nonmetallic minerals (NM) are capital intensive in every country. Basic metals (BM) and food (FD) are also classiffed as capital-intensive industries, because BM is labor intensive only in the Netherlands and FD only in Canada and Japan. Paper (PA) is a borderine industry, capital intensive in half the countries. Comparing the distance between the capital-labor ratios and the average in manufacturing, countries with capital-intensive paper industries lie farther from the average. Thus, PA is classified as capital intensive.

Industries can also be consistently compared across countries. For instance, aggregate manufacturing (MF) is the most capital intensive in the Netherlands and Sweden, and the most labor intensive in the UK and Japan. Textiles (TX) is the most labor intensive in the US, and chemicals $(\mathrm{CH})$ the most capital intensive in the Netherlands. The variation in the capital-labor ratio across countries is largest in paper (PA) and basic metals (BM).

\section{An Empixical Model of the Stolper-Samuelson Theorem}

The empirical model incorporates the assumptions and structure of the underlying theory. Variables which are exogenous in theory are included as independent variables in the regressions. Imperfections in the labor market are controlled by the use of independent variables. The key to specifying a theory is to include the structure of the model which leads to the theoretical outcomes.

In the Stolper-Samuelson theorem, the ratio of wages to rents is the dependent variable, while output prices and factor endowments are independent exogenous variables. Including influences due to imperfections in the labor market, consider the following $\log$ linear model: 
Table 1. Industrial Factor Intensity, Average for 1970-85

Rank (\$ K/L) $K$ or L intensivet

\begin{tabular}{|c|c|c|c|c|c|c|c|c|c|c|c|c|}
\hline \multirow[b]{2}{*}{ Indus'ry山 } & \multicolumn{12}{|c|}{ Country } \\
\hline & $B L$ & $C N$ & $D U$ & $D N$ & $F R$ & $I T$ & $J P$ & $N L$ & $N R$ & SW & $U K$ & $U S$ \\
\hline$T X$ & $2(34) L$ & $1(24) L$ & $3(30) L$ & $2(26) L$ & $1(31) L$ & $2(22) L$ & $4(29) L$ & $4(56) L$ & $1(25) L$ & $2(33) L$ & $2(24) L$ & $1(18) L$ \\
\hline$O M$ & $4(55) L$ & $2(28) L$ & $1(24) L$ & $1(19) L$ & $3(48) L$ & - & $1(13) 2$ & $1(31)_{L}$ & $2(33) L$ & $1(7) L$ & $1(23) L$ & $2(23) L$ \\
\hline WD & - & $4(50) L$ & $4(39) L$ & $4(39) L$ & - & $1(20) L$ & - & - & $4(44) L$ & $4(50) L$ & - & $3(48) L$ \\
\hline ME & $1(31) L$ & $3(42) L$ & $2(25) L$ & $3(30) L$ & $2(39) L$ & $3(37) L$ & $2(27) L$ & $3(56) L$ & $3(35) L$ & $3(50) L$ & $3(26) L$ & $4(32) L$ \\
\hline PA & $3(51) L$ & $6(112) K$ & $5(46) K$ & $5(41) L$ & $4(53) K$ & $4(56) K$ & $6(109) K$ & $2(48) L$ & $5(49) L$ & $y(115) K$ & $4(31) L$ & $5(48) L$ \\
\hline FD & $5(68) K$ & $5(58) L$ & $6(55) K$ & $6(55) K$ & $8(75) K$ & $6(65) K$ & $3(29) L$ & $6(78) K$ & $6(64) K$ & $6(78) K$ & $5(53) K$ & $6(54) K$ \\
\hline NM & $7(75) K$ & $9(282) K$ & $8(62) K$ & $9(85) K$ & $G(72) K$ & $5(51) K$ & $5(50) K$ & $7(82) K$ & $7(76) K$ & $5(72) K$ & $6(56) K$ & $7(66) K$ \\
\hline $\mathrm{CH}$ & $8(1.04) K$ & $7(1.20) K$ & $7(58) K$ & $8(80) K$ & $7(73) K$ & $7(109) K$ & $7(140) K$ & $8(145) K$ & $9(123) K$ & $7(106) K$ & $8(86) K$ & $8(109) K$ \\
\hline $\begin{array}{l}\text { BM } \\
\text { MF }\end{array}$ & $\begin{array}{c}6(70) K \\
(56)\end{array}$ & $\begin{array}{c}8(164) K \\
(60)\end{array}$ & $\begin{array}{c}9(79) K \\
(40)\end{array}$ & $\begin{array}{c}7(74) K \\
(44)\end{array}$ & $\begin{array}{c}5(60) K \\
(51)\end{array}$ & $\begin{array}{l}8(191) K \\
(52)\end{array}$ & $\begin{array}{c}8(145) K \\
(39)\end{array}$ & $\begin{array}{c}5(60) L \\
(68)\end{array}$ & $\begin{array}{c}8(108) K \\
(55)\end{array}$ & $\begin{array}{c}8(116) K \\
(68)\end{array}$ & $\begin{array}{c}7(59) \mathcal{K} \\
(39)\end{array}$ & $\begin{array}{c}9(172) K \\
(50)\end{array}$ \\
\hline
\end{tabular}

- Source: OECD International Secroral Datahank, 1989.

¿1-9, ranking from the most labor intensive to the most capital incensive industries; (), thousands of dollars ar $K$ per $L ; K$ or $L$ intensive, capital or lator intensive relative to average in manulacturing (MF) in each oountry.

‘BL, Belgium; CN, Canada; DU, Germany; DN, Denmark; FR, Frauce; IT, Italy; JP, Japan; NL, Netherlands; NR, Norway; SW, Swreden; UK, Uniled Kingdon; US, Uniled States.

${ }^{2}$ TX, textiles; OM, other manufactures; WD, wood, wood products; ME, machinery, equipment; PA, paper, printing, publishing; FD, food, beverages, tobacon; NM, noumelitlic minerals; CH, chemicals; BM, basic metals; Mls, aggregate manufacluring. 


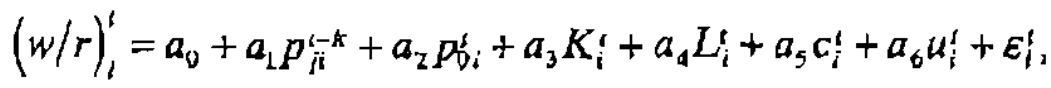

where industries are indexed by $j=1, \ldots, 9$; countries by $i=1, \ldots, 12$; and time by $t$ $=1970, \ldots, 1985$. Variables in equation (1) are expressed in logarithms and defined as:

$(w / r)^{t}$, the wage relative to the return to capital in manufacturing;

$p_{\beta_{1}+*} \quad$ the lagged price of output in isolated industry $j$;

$p_{v i r}^{t} \quad$ the aggregate price in the other sector;

$K_{i}^{\prime}, \quad$ the capital endowment;

$L_{i}$, the labor endowment;

ir coefficient of variation in wages across industries within each country;

$u_{i}^{t}, \quad$ the unemployment rate; and

$\varepsilon_{t}^{i}, \quad$ random error.

The Stolper-Samuelson theorem predicts $a_{1}$ will be positive (negative) if the isolated industry $j$ is labor (capital) intensive. The aggregate price of other goods $p_{\diamond}$ is included as an exogenous variable. To construct this price index for industry $j$, output in industry $j$ is first subtracted from manulacturing output, $y_{o}=y_{M}-y_{k}$, where $y$ represents the value of output in 1980 US dollars. The size of industry $j$ relative to the other industries is $\sigma_{l} \equiv y_{j} / y_{v}$. For industry $j$, the aggregate price index of the other goods is $p_{v}=\Sigma_{\mid \pm j} \sigma_{i} p_{l}$. Aggregation reduces the model to two industries. In theory, the price of this other good is held constant to isolate the Stolper-Samuelson effect for the industry in question. In the data, there is variation in prices across countries and time. Including $p_{0}$ allows interpretation of the other coefficients in (1) as though the aggregate price of other goods were constant. The parameters are thus partial derivatives in the comparative static model.

In the Heckscher-Ohlin model, changes in $K$ and $L$ should have no effect on $w / r$, the factor-price equalization result. Including $K$ and $L$ in (1) effectively holds endowments constant to concentrate on the effect of price changes captured by $a_{1}$.

The coefficient of variation of wages $c$ is the standard deviation of the wage divided by its mean. In theory, wages are equal across industries within a country due to the assumptions of labor homogeneity and mobility. Ideally, $c$ would be zero, but there is some variation in wages across industries. Including the coefficient of variation has the effect of controlling this industrial wage variability. The price coefficient $a_{\lambda}$ can be interpreted as though wage variability were constant.

The unemployment rate $u$ is included because of the theoretical assumption of full employment. There is, however, variation in unemployment across countries and time in the data. Changes in unemployment might affect the general-equilibrium ratios of wages to rent or capital to labor. Including $u$ makes the other coefficients, most importantly $a_{1}$, partial derivatives holding unemployment constant.

Reliable figures for the return to capital, included in the dependent variable in (1), are not available. The ratio of wages to rents, however, directly affects the ratio of capital to labor, which is reported in the data. In the following estimations, the endogenous capital-labor ratio in each industry serves as a proxy for the ratio of wages to rents.

In the Stolper-Samuelson theorem, any change in $p_{f}$ should be due to a change in the international market or in the demand for good $j$. An observed change in $p_{f}$ could, however, be caused by a shift in technology or supply. Deardorff and Hakura (1993, p. 27) point out that in studying the Stolper-Samuelson process, the source of price changes must be known. A negative technology shock, for instance, would decrease 
domestic supply and raise the price of output. There is then some ambiguity with respect to the final position of the unit-value isoquant, which would shift away from the origin with the technology shock, but toward the origin with the resulting higher price. The net effect could be a unit-value isoquant farther from the origin, which would mean a lower relative wage occurring along with the higher price of the labor-intensive good. A price change would then be associated with the opposite of the predicted Stolper-Samuelson effect.

Output of industry $j$ is used as a proxy for price. The assumption is that technology changes have larger effects on the unit-isoquant position than the related price changes when supply shocks occur. This assumption works better with more elastic demand. In these competitive models, the typical assumption is perfect competition, which fits this high level of aggregation. If isolated industry $j$ is labor intensive, higher output is then accompanied by an increase in the ratio of wages to rents. In the process, the capitallabor ratio rises. Higher outputs in capital-intensive industries are associated with lower capital-labor ratios.

Industrial output is normalized by total manufacturing output. The share of industry j output in total manufacturing output, $s_{j}$, becomes the exogenous yariable of interest. Output shares control for the different sizes of the same industry across countries, reflecting performance of each industry relative to all manufacturing. Output shares are not used to proxy the price of the other sector because $s_{u}=1-s_{j}$.

This analysis leads to the estimation of

$$
(K / L)_{j i}^{\prime}=b_{0}+b_{1} s_{j t}+b_{2} p_{01}^{\prime}+b_{3} K_{i}^{\prime}+b_{4} L_{l}^{\prime}+b_{5} c_{i}^{\prime}+b_{6} L_{j}^{\prime}+\eta_{j i}^{\prime}
$$

where $\eta_{j l}^{\prime}$ is the random error term. The Stolper-Samuelson variable $s_{j 1}$ the share of isolated industry $j$ in manufacturing, is lagged to allow for adjustment over time.

\section{Results of the Stolper-Samuelson Estimation}

Equation (2) is estimated in a pooled regression for each industry across the 12 sample countries over the 16 years. Although the countries are all developed industrial economies, they differ in institutions, public policy, and business laws. To control for this heterogeneity, (2) is estimated with a separate constant term for each country.

Prelimizary tests indicate heteroskedasticity and first-order autocorelation. The Parks (1967) method is applied because it assumes residuals are heteroskedastic, contemporaneously correlated, and serially correlated of first order in pooled data. The model is estimated in loganithms, and the coefficients are interpreted as elasticities.

Regression estimates of (2) are reported in Table 2. The Stolper-Samuelson theorem in the present model predicts that in the labor-intensive industries (TX, OM, WD, ME)

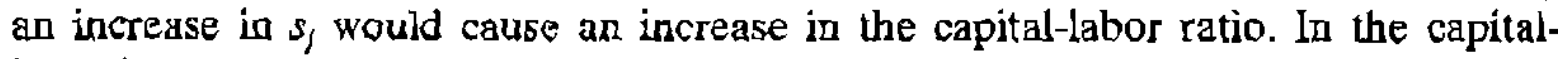
intensive industries (PA, FD, NM, CH, BM) an increase in $s_{j}$ should lower the capitallabor ratio. This prediction holds for five of the nine industries: OM, ME, PA, NM, and $\mathrm{BM}$. The coefficients for WD and FD have the right sign, but are insignificant. Significant opposite signs are found in only TX and CM. The Stolper-Samuelson prediction is thus rejected in only two of nine industries. Among the labor-intensive industries, $\mathrm{OM}$ and ME have correct and signiticant positive signs, and WD has the correct sign but is insignificant. In three of the five capital-intensive industries, correct significant negative effects occur. The signs of the other two industries do not coincide with theary, and $\mathrm{CH}$ has a significant positive sign. The Stolper-Samuelson mechanism performs about as well in both labor-and capital-intensive industries. 
th

he

se.

ld

ive

ed

jgy

ges

. In

this

nen

tal-

vith

stry

:est.

ries,

ares

(2)

re of

mple

zono-

$r$ this

The

lastic,

1. The

ies.

zorem

', ME)

apital-

apital-

$\mathrm{M}$, and

jignifi-

jiction

ustries,

ct sign ificant le with hanism

Table 2. Stolper-Samuelsan Estimation: Regression Resulss of Equation (2) with Dependent Variable $(K / L)_{i}$

\begin{tabular}{|c|c|c|c|c|c|c|c|c|}
\hline \multirow[b]{2}{*}{ Industry } & \multicolumn{6}{|c|}{ In vuriable (+- statistic) } & \multirow[b]{2}{*}{$R^{2 i}$} & \multirow[b]{2}{*}{$M S E^{ل}$} \\
\hline & $S_{j l}$ & $P_{0}^{f}$ & $\mathbf{K}$ & $L_{!}$ & $\mathbf{C}_{\mathbf{i}}^{1}$ & $u_{i}^{i}$ & & \\
\hline TX & $\begin{array}{l}-0.08 \\
(16.4)\end{array}$ & $\begin{array}{c}-0.04 \\
(4.73)\end{array}$ & $\begin{array}{l}1.08 \\
(40.9)\end{array}$ & $\begin{array}{l}-0.84 \\
(31.9)\end{array}$ & $\begin{array}{l}-0.20 \\
(11.2)\end{array}$ & $\begin{array}{c}0.05 \\
(6.23)\end{array}$ & 0.16 & 1.02 \\
\hline OM & $\begin{array}{r}0.04 \\
(1.81)\end{array}$ & $\begin{array}{c}-0.03 \\
(4.17)\end{array}$ & $\begin{array}{l}0.91 \\
(16.6)\end{array}$ & $\begin{array}{l}-0.66 \\
(15.3)\end{array}$ & $\begin{array}{l}-0.12 \\
(3.95)\end{array}$ & $\begin{array}{c}0.07 \\
(7.40)\end{array}$ & 0.72 & 1.01 \\
\hline WD & $\begin{array}{r}0.07 \\
(1.24)\end{array}$ & $\begin{array}{c}0.002 \\
(0.17)\end{array}$ & $\begin{array}{l}0.90 \\
(24.2)\end{array}$ & $\begin{array}{l}-1.59 \\
(11.6)\end{array}$ & $\begin{array}{r}0.07 \\
(2.21)\end{array}$ & $\begin{array}{c}-0.03 \\
(3.02)\end{array}$ & 0.97 & 1.05 \\
\hline ME & $\begin{array}{r}0.25 \\
(31.3)\end{array}$ & $\begin{array}{c}0.01 \\
(1.70)\end{array}$ & $\begin{array}{c}0.95 \\
(106.7)\end{array}$ & $\begin{array}{l}-1.04 \\
(82.6)\end{array}$ & $\begin{array}{r}0.10 \\
(18.6)\end{array}$ & $\begin{array}{c}0.01 \\
(2.31)\end{array}$ & 0.69 & 1.05 \\
\hline PA & $\begin{array}{l}-0.27 \\
(9.86)\end{array}$ & $\begin{array}{l}-0.01 \\
(2.00)\end{array}$ & $\begin{array}{c}0.64 \\
(23.4)\end{array}$ & $\begin{array}{l}-0.93 \\
(35.2)\end{array}$ & $\begin{array}{r}0.02 \\
(2.44)\end{array}$ & $\begin{array}{c}0.04 \\
(5.50)\end{array}$ & 0.97 & 1.03 \\
\hline FD & $\begin{array}{r}0.05 \\
(1.46)\end{array}$ & $\begin{array}{c}-0.02 \\
(3.12)\end{array}$ & $\begin{array}{l}0.73 \\
(27.4)\end{array}$ & $\begin{array}{l}-0.68 \\
(20.8)\end{array}$ & $\begin{array}{l}-0.02 \\
(1.13)\end{array}$ & $\begin{array}{c}0.03 \\
(4.20)\end{array}$ & 0.97 & 1.02 \\
\hline NM & $\begin{array}{l}-0.35 \\
(30.8)\end{array}$ & $\begin{array}{l}-0.04 \\
(19.3)\end{array}$ & $\begin{array}{l}0.77 \\
(53.5)\end{array}$ & $\begin{array}{l}-0.77 \\
(63.6)\end{array}$ & $\begin{array}{r}0.05 \\
(9.01)\end{array}$ & $\begin{array}{c}0.06 \\
(22.6)\end{array}$ & 0.98 & 1.03 \\
\hline $\mathrm{CH}$ & $\begin{array}{r}0.05 \\
(2.28)\end{array}$ & $\begin{array}{r}-0.004 \\
(0.63)\end{array}$ & $\begin{array}{l}0.84 \\
(31.1)\end{array}$ & $\begin{array}{c}-0.77 \\
(19.8)\end{array}$ & $\begin{array}{r}0.06 \\
(4.81)\end{array}$ & $\begin{array}{c}-0.02 \\
(3.18)\end{array}$ & 0.56 & 1.07 \\
\hline $\mathrm{BM}$ & $\begin{array}{l}-0.24 \\
(26.7)\end{array}$ & $\begin{array}{l}-0.02 \\
(5.16)\end{array}$ & $\begin{array}{l}0.77 \\
(56.4)\end{array}$ & $\begin{array}{l}-1.24 \\
(54.5)\end{array}$ & $\begin{array}{r}0.01 \\
(0.61)\end{array}$ & $\begin{array}{c}-0.002 \\
(0.62)\end{array}$ & 0.90 & 0.99 \\
\hline
\end{tabular}

- $S_{j,}$, output share; $p h$, other prices; $K_{i}$, capital endowmenl; $L_{j}$, labor endowment; $c_{i}$, coefficient of variation in wgges; $\mu$, unemployment.

"TX, textiles; OM, other manufactures; WD, wood, wood products; ME, machinery, equipment; PA, paper, printing, publishing; PD, Eood, beverages, tobacco; NM, nonmetallic minerals; CH, chemicals; BM, basic metals; MF, aggregate manufacturing.

‘ $R^{\mathbf{z}}$, groodness of fit.

MSE, mean square error.

The capital endowment $K$; coefficient is significantly positive in every industry, and the labor endowment $L i$ siguificantly negative, which indicates that factor endowments affect input ratios and underlying factor prices. A higher manufacturing capital endowment means a higher ratio of wages to rents and a higher capital-labor ratio in each industry. A higher labor endowment lowers both the wage-rent ratio and the industrial capital-labor ratio. This result implies that the static factor-price equalization property does not hold in this data set. Factor prices depend on factor endowments. Rassekh (1993) uses the same data, however, and finds dynamic wage convergence in each of these industries.

The coeficient of variation in wages $c_{i}$ is significant except in FD and BM. Significance means that enough wage variation occurs across industries and time to affect the industry's capital-labor ratio. The significance of $c_{f}^{r}$ indicates that labor is not homogeneous or completely mobile across industries. There are ways to modify the Heckscher-Ohlin model to include imperfections in the labor market and maintain the basic intuition of the Stolper-Samuelson theorem. Including $c_{i}^{f}$ as a variable allows the share coefficient to be interpreted as though the variation in wages were constant. The unemployment term $u_{i}^{t}$ is significant in every industry except BM, which indicates that unemployment generally affects the capital-labor and wage-rent tatios. 
Table 3. Specific-Factors Model: Regressian Results of Equation (3) with Dependent Variable $\mathrm{L}_{\mathbf{i}} \mathrm{u}$

\begin{tabular}{|c|c|c|c|c|c|c|c|c|}
\hline \multirow[b]{2}{*}{ Industrye } & \multicolumn{6}{|c|}{ 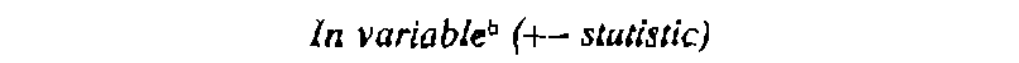 } & \multirow[b]{2}{*}{$R^{2 d}$} & \multirow[b]{2}{*}{$M S E^{\circ}$} \\
\hline & $S_{j}$ & Pứl & $\mathbf{K}_{\mathbf{j i}}^{1}$ & $\mathrm{~L}$ & $\mathfrak{c}_{1}^{\prime}$ & uf & & \\
\hline $\mathrm{TX}$ & $\begin{array}{c}0.07 \\
(0.79)\end{array}$ & $\begin{array}{c}-0.03 \\
(1.90)\end{array}$ & $\begin{array}{r}0.63 \\
(7.18)\end{array}$ & $\begin{array}{c}1.20 \\
(12.4)\end{array}$ & $\begin{array}{r}0.28 \\
(6.55)\end{array}$ & $\begin{array}{l}-0.03 \\
(2.37)\end{array}$ & 0.99 & 0.004 \\
\hline OM & $\begin{array}{c}0.06 \\
(2.00)\end{array}$ & $\begin{array}{r}-0.002 \\
(0.20)\end{array}$ & $\begin{array}{l}-0.01 \\
(0.64)\end{array}$ & $\begin{array}{c}0.44 \\
(4.34)\end{array}$ & $\begin{array}{r}0.11 \\
(2.60)\end{array}$ & $\begin{array}{r}-0.06 \\
(4.54)\end{array}$ & 0.99 & 0.008 \\
\hline WD & $\begin{array}{c}0.33 \\
(6.69)\end{array}$ & $\begin{array}{c}0.01 \\
(0.67)\end{array}$ & $\begin{array}{l}-0.02 \\
(0.22)\end{array}$ & $\begin{array}{c}1.41 \\
(14.3)\end{array}$ & $\begin{array}{l}-0.10 \\
(2.08)\end{array}$ & $\begin{array}{r}0.05 \\
(3.28)\end{array}$ & 0.99 & 0.002 \\
\hline ME & $\begin{array}{c}0.05 \\
(2.62)\end{array}$ & $\begin{array}{l}-0.02 \\
(7.25)\end{array}$ & $\begin{array}{r}0.11 \\
(7.75)\end{array}$ & $\begin{array}{c}1.16 \\
(43.6)\end{array}$ & $\begin{array}{l}-0.02 \\
(1.56)\end{array}$ & $\begin{array}{r}0.02 \\
(7.16)\end{array}$ & 0.99 & 0.001 \\
\hline PA & $\begin{array}{c}0.17 \\
(5.52)\end{array}$ & $\begin{array}{r}0.004 \\
(0.43)\end{array}$ & $\begin{array}{l}-0.09 \\
(1.89)\end{array}$ & $\begin{array}{c}0.53 \\
(7.99)\end{array}$ & $\begin{array}{r}0.06 \\
(2.61)\end{array}$ & $\begin{array}{l}-0.05 \\
(5.67)\end{array}$ & 0.99 & 0.003 \\
\hline FD & $\begin{array}{c}0.06 \\
(2.29)\end{array}$ & $\begin{array}{c}0.02 \\
(2.67)\end{array}$ & $\begin{array}{r}0.19 \\
(3.59)\end{array}$ & $\begin{array}{c}0.52 \\
(12.1)\end{array}$ & $\begin{array}{r}0.06 \\
(3.31)\end{array}$ & $\begin{array}{l}-0.01 \\
(2.50)\end{array}$ & 0.99 & 0.002 \\
\hline NM & $\begin{array}{c}0.22 \\
(9.21)\end{array}$ & $\begin{array}{c}0.04 \\
(5.04)\end{array}$ & $\begin{array}{r}-0.05 \\
(2.88)\end{array}$ & $\begin{array}{c}1.18 \\
(21.1)\end{array}$ & $\begin{array}{r}-0.08 \\
\langle 3.02)\end{array}$ & $\begin{array}{c}0.0 \mathrm{l} \\
(1.39)\end{array}$ & 0.99 & 0.007 \\
\hline $\mathrm{CH}$ & $\begin{array}{c}0.07 \\
(3.66)\end{array}$ & $\begin{array}{c}-0.02 \\
(3.95)\end{array}$ & $\begin{array}{r}0.33 \\
(9.31)\end{array}$ & $\begin{array}{c}0.77 \\
(19.9)\end{array}$ & $\begin{array}{r}-0.06 \\
(2.89)\end{array}$ & $\begin{array}{r}0.04 \\
(6.29)\end{array}$ & 0.59 & 0.001 \\
\hline $\mathrm{BM}$ & $\begin{array}{c}0.02 \\
(1.17)\end{array}$ & $\begin{array}{c}0.02 \\
(2.91)\end{array}$ & $\begin{array}{r}0.08 \\
(1.26)\end{array}$ & $\begin{array}{c}1.10 \\
(15.7)\end{array}$ & $\begin{array}{l}-0.06 \\
(1.93)\end{array}$ & $\begin{array}{r}0.02 \\
(2.17)\end{array}$ & 0.99 & 0.010 \\
\hline
\end{tabular}

-This model is estimated with capital inputs of other industries individually included, but these coeflicients are not reported.

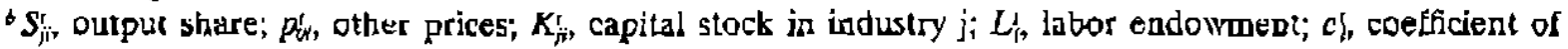
variation in wages; $u$, unemployment.

'IX, textiles; OM, other manufactures; WD, wood, wood products; ME, machinery, equipment; PA, paper, printing, publishing; FD, food, beverages, tobacco; NM, aonnetallic mineralk; CH, chemicals; BM, basic metals; MF, uggregate manufzcturing.

${ }^{\top} R^{2}$, goodness of Git.

¿MSE, mean square error.

Adjustrnent in the capital-labor ratio and the underlying wage-rent ratio can be expected to take some time. Equation (2) was also estimated including various combinations of several lags of the share variable. To determine the long-run impact, an econometric procedure described by Harvey (1990, chapter 7) is applied. Accordingly, (2) is estimated for each industry with the first and second lags of the share variable. The equation is then re-estimated with three lags. To determine the optimum lags, the Akaike Intormation Criterion described by Harvey $(1990$, p. 176) is applied. Results suggest thal $O M$ and WD need three lags, while the other industries need only two lags. The reported parameters for the share variable in Table 2 are calculated by summing the coefficients of the optimum lags.

\section{An Empirical Specific-Factors Model}

In estimating the specific-factors model, the capital input $K_{j i}^{\prime}$ is assumed to be the specific factor in the isolated industry, and should be held constant. Therefore, $K_{\text {ji }}^{\prime}$ becomes an exogenous variable. Industrial labor input $L_{f t}^{f}$ is treated as the dependent variable. Capital input in each of the industries is also separately held constant. The following specific-factors equation is then estimated for eaciłı industry $j$ : 


$$
L_{j i}^{\prime}=c_{0}+c_{1} s_{j i}^{\prime}+c_{2} p_{0 i}^{\prime}+c_{3} K_{j i}^{\prime}+\sum_{h \neq j} c_{k} K_{h l}^{\prime}+c_{4} L_{i}^{\prime}+c_{5} c_{i}^{\prime}+c_{6} L_{i}^{\prime}+\mu_{j i}^{\prime} .
$$

Most variables in (3) are repeated from (2), and $\mu_{j i}^{t}$ represents a random-error term. Equation (3) is also estimated with a separate intercept for each country. The same discussion about using output shares as the Stolper-Samuelson variable applies in the specific-factors model.

A higher price in any industry in the specific-factors model lowers the ratio of wages to rents in the industry, In the present estimation, a higher output share in an industry should raise labor input. A positive $c_{1}$ is expected for every industry.

The total endowment of manufacturing labor is included as an exogenous variable. Coefficients for the total labor endowment and the capital inputs are not predicted to be zero as in the Heckscher-Ohlin model. Other industrial capital $K_{j i}^{\prime}(j \neq i)$ represents the input of capital in each of the other industries. An increase in the capital of another sector causes labor to be drawn away from sector $j$. Thus, the coelificients for $K_{j}$ are expected to be negative. An increase in the labor endowment $L$ i causes every industry to hire labor as wages fall. Thus, the coefficient $c_{4}$ should be positive.

Table 3 presents results from the pooled estimation of the specific-factors model in (3) for each industry. Heteroskedasticity and serial correlation of order one are again detected, and the Parks method is applied. The model is estimated in logarithms.

The coefficient $c_{1}$ of the output share $s_{j i}$ is positive in every industry and significant except in TX and BM. The fact that $c_{1}$ is not negative in any industry is strong support for the specific-factors model.

An increase in the capital input $K_{j i}$ in an industry should raise the labor input in the industry, as labor is attracted from other industries. Significant positive coefficients for $K_{j i}^{\prime}$ occur in five industries (TX, ME, FD, CH, and BM) and only two significant negative signs occur (PA and NM). These coefficients are not reported to economize on space.

Increases in the labor endowment would be spread across industries, as the consistently significant positive coefficients indicate. The coefficient of variation in wages $\epsilon_{i}^{t}$ is significant for every industry, as is unemployment $u_{r}^{\prime}$ except for industry NM.

The Parks method used to estimate the two models does not automatically report the $R^{2}$. To calculate measures of goodness of fit, actual values of the dependent variables are regressed on their fitted values. The resulting measures are reported in Tables 2 and 3. These values should be interpreted only as an indication of goodness of fit because they may not have the usual distribution associated with ordinary least squares.

\section{Conclusions}

The specification in this paper captures the general-equilibrium predictions of the Stolper-Samuelson theorem and the specific-lactors model using industrial data. In the Stolper-Samuelson theorem, the dependent variable is the ratio of capital to labor in each industry. Independent variables in the estimation are suggested by the assumptions of theory. In five of nine industries, results conform with the Stolper-Samuelson theorem, and its basic implication is rejected in only two industries. Treating industrial capital as specific and exogenous, an empirical specific-factors model is specified. Seven of nine industries conform with the basic prediction of the specific-factors model, and no industry presents a contradictory significant result.

The present paper's focus is on the general-equilibrium structure of production, not on differences in countries or on levels of international trade. Variation in output 
prices, positively correlated with outputs, typically have the predicted general-equilibrium effects on inputs. The Stolper-Samuelson theorem and specific-factors model apply across a wide range of common circumstances. These core theoretical models should not be dismissed offhand as empirically irrelevant.

The factor-proportions model springs from the way economists since Ricardo and Walras view an economy. There is a continuing challenge to formulate generalequilibrium models with many goods which clarify liaks between the prices of goods and the prices of factors. The present study shows that the Stolper-Samueison theorem and specific-factors model, even in their simplest two-factor yersions, have empirical content. Comparing the performance of the two models, the specific-factors model generates somewhat stronger results.

\section{References}

Bhagwati, Jagdish, and Vivek Dehejia, "Freer Trade and Wages of the Unskilled: Is Marx Sirking Again?" in Jagdish Bhagwati and Marvin H. Kosters (ed.), Trade and Wages, Washington, D.C.: American Enterprise Institute, 1993.

Branson, William H., and Nicolas Monoyios, "Faclor Inputs in US Trade," Journal af Intemational Economics 7 (1977):111-31.

Chang, Winston, "Some Theorems of Trade and General Equilibrium with Many Goods and Factors," Economerrica 47 (1979):709-26.

Clark, Don, Richard Hofler, and Henry Thompson, "Separability of Capital and Labor in US Manufacturing," Economics Letters' 26 (1988):197-201.

Deardorff, Alan V., and Dalia Hakura, "Trade and Wages: What Are the Questions?" in J. Bhagwati and M. H. Kosters (ed.), Trade and Wages, Washington, D.C.: American Enterprise Instituce, 1943.

Ethier, Wilfred, "Some of the Theorems of International Trade with Many Goods and Factors," Journal of International Economics 14 (1984):199-206.

Gaston, Noel, and Danie! Trefler, "Protection, Trade, and Wages: Evidence from U.S. Manufacturing," Industrial Labor Relations Review 47 (1994):574-93.

Harvey, Andrew C., Econometric Analysis of Time Series, zad ed., Cambridge: The MrT Press, 1990.

Jones, Ron, "A Three-Factor Model in Theory, Trade, and History," in J. Bhagwati, R. Mundell, R. Jones and J. Vanek (ed.), Trade, Balunce of Paymerts, and Growth, Ansterdan: North Holland, 1971.

Krugman, Paul R., and Robert Z. Lawrence, "Trade, Jobs, and Wages," Scientific American 270(4) (1994):22-7.

Lawrence, Robert $Z_{\text {, }}$ and Matthew J. Slaughter, "International Trade and American Wages in the 1980's; Giant Sucking Sound or Small Hiccup'?" Brookings Papers on Economic Activity, 1993, Vol 2, pp 115-80.

Leamer, Edward E, Sources of Comparative Advantage, Cambridge: The MГT Press, 1984.

-_. "Testing Trade Theory," in David Greenaway and L. Alan Winters (ed.), Swrveys in International Trade, Cambridge: Basil Elackwell, 1994a.

-_ - "Wage Elfects of a US-Mexican Free Trade Agreement," in Peter Garber (ed.), The Mexico-US Free Trade Agreement, Cambridge: The MTT Press, $1994 \mathrm{~b}$.

Magee, Stephen P., "Three Simple Tests of the Stolper-Samuelson Theorem," in Peter Oppenheimer (ed.), Issues in Iniernational Economics, London: Oriel Press, 1980.

Neaxy, J. Peter, "Short-Run Capital Specificity and the Pure Theory of International Trade," Economic Journal 88 (1978):488-510.

OECD, The International Sectoral Databank on Microcomputer Diskette, Paris: Organisation for Economic Cooperation and Devolopment, 1989. 
both Serially and Comiemporaneously Correlated," Journal of the American Statistical Association 62 (1967):500-509.

Rassekh, Farhad, "International Trade and the Relative Dispersion of Industrial Wages and Production Techniques in Fourteen OECD Countries, 1970-1985," Open Economics Review 4 (1993):325-44.

Samuelson, Pau, "Ohlin Was Right," Swedish Joumal of Economics 73 (1971):365-84.

Stolper, Wolfgang F., and Paul Samuelson, "Protection and Real Wages," Review of Economic Studies 9 (1941):58-73.

Thompson, Henry, "Complementarity in a Simple General Equilibrium Model," Canadian Jaurnal of Economics 18 (1985):616-21. 